\section{Peer-reviewed paper defends theory of intelligent design}

\section{Jim Giles}

A new front has opened up in the battle between scientists and advocates of intelligent design, a theory that rejects evolution and is regarded by its critics as another term for creationism.

A scientific journal has published a paper that argues in favour of intelligent design - the first time such material has appeared in a peer-reviewed publication, according to biologists who track the issue. The paper appeared in a lowimpact journal, Proceedings of the Biological Society of Washington. But critics say that it could still be used by advocates of intelligent design to get the subject on to US school curricula (see Nature 416, 250; 2002).

The article comes from the Discovery Institute in Seattle, Washington, a leading promoter of the theory. In the article, senior fellow Stephen Meyer uses information theory and other techniques to argue that the complexity of living organisms cannot be explained by darwinian evolution (S. C. Meyer Proc. Biol. Soc. Wash. 117, 213-239; 2004).

Many of Meyer's arguments have already been aired by advocates of intelligent design, but critics say that publication will be used to back up claims that the theory is scientifically valid.

Kenneth Miller, a cell biologist at Brown University in Providence, Rhode Island, who has argued against Meyer in public debates, does not doubt that this will happen. "They've tried very hard to get material into peer-reviewed journals."

Richard Sternberg, a taxonomist at the National Center for Biotechnology Information in Bethesda, Maryland, was editor of the journal publishing the Meyer paper when it was reviewed and accepted. Sternberg is also on the editorial board of the Baraminology Study Group, which publishes papers on "scientific research in creation biology". He says the paper was seen and approved by three well-qualified referees.

Meyer's article has attracted a lengthy rebuttal on The Panda's Thumb, a website devoted to evolutionary theory. But Miller says that, despite criticism of the journal, versions of the theory will find their way into the scientific literature at some point. Arguments for it can be written, he says, as reappraisals of certain aspects of evolution rather than outright rejection. "Peer review isn't a guarantee of accuracy," he adds. "That is especially true of review articles."

\section{Conservers plead for funds to protect Europe's heritage}

\section{Alison Abbott, London}

Tens of millions of tourists visit Europe each year to enjoy its cultural heritage. And if they were aware of it, they would no doubt cheer the work of the scientists who are preserving that heritage - fighting the harm caused by pollution, by the natural processes of decay and by the tourists themselves.

But at a meeting in London from 1 to 3 September, the European network of these interdisciplinary researchers declared that its support is diminishing.

For more than a decade, the European Commission has funded, at a modest level, programmes designed to analyse damage to cultural heritage and to prevent, monitor and repair such harm. The scientists involved draw on disciplines that include laser optics and nanotechnology; they consider all aspects of decaying heritage, from ancient manuscripts to archaeological sites.

The support they have had from the European Commission has fallen from $€ 40$ million (US\$48 million) in the fifth framework programme (1998-2002) to $€ 10$ million in the current, sixth programme. "We worry that the trend of undervaluing cultural heritage is worsening," says May Cassar, head of the Centre for Sustainable Heritage at University College London, who organized the meeting.

The commission is currently the only source of funding in Europe that is specifically earmarked for generic research into sustaining cultural heritage, although individual groups sometimes win small grants from national sources. As drafting of the seventh programme, which starts in 2007, begins in earnest, the researchers want political leaders to recognize the value of their work to Europe's vast tourism industry.

One project, called Caramel, has led to the development of monitors of inorganic and organic atmospheric pollutants, which include the carbon that is responsible for blackening buildings. These unobtrusive monitors can be placed at key sites, reports Cristina Sabbioni, a physicist at the National Research Council's Institute of Atmospheric Sciences and Climate in Bologna, who is involved in the project. Its scientists have been able to quantify the atmospheric levels of small particles, which deposit carbon more quickly than large particles, during rush hours in tourist cities such as Florence and Seville. And local authorities in Seville have decided to restrict traffic flow past its main cathedral, which is currently being cleaned, in direct response to the Caramel data.

Another project, called LaserACT, diagnoses degradation in works of art using lasers. Such lasers are also being used to clean sensitive stone, including the west frieze of the Parthenon, which has been scrubbed by technology developed at the Institute of Electronic Structure and Laser, Crete, in collaboration with ESMA, the group responsible for the conservation of the Acropolis.

Now biologists are joining physicists in the conservation cause, the meeting heard. Microbiologists are analysing the colonies of bacteria that form in caves and catacombs where visitors have disturbed steady light and air conditions and caused damage to the artwork and structures. A project called BioBRUSH is researching calcite-forming microorganisms, which may remove salty crusts on stone and lay down a hard calcite layer to protect it from further damage. "There is a long way to go before this technology could be applied with confidence to important monuments," cautions BioBRUSH scientist Eric May of the University of Portsmouth, UK. "We need reliable sources of funds to develop this type of approach," he says. 